\title{
Article \\ Tax Avoidance, Tax Risk, and Corporate Governance: Evidence from Korea
}

\author{
Jihwan Choi (1) and Hyungju Park* \\ Department of Accounting, Hanyang University, Seoul 04763, Korea; jdtoday@hanyang.ac.kr \\ * Correspondence: phj820@hanyang.ac.kr
}

Citation: Choi, J.; Park, H. Tax Avoidance, Tax Risk, and Corporate Governance: Evidence from Korea. Sustainability 2022, 14, 469. https:// doi.org/10.3390/su14010469

Academic Editors: Marc A. Rosen and David K. Ding

Received: 25 November 2021 Accepted: 30 December 2021

Published: 2 January 2022

Publisher's Note: MDPI stays neutral with regard to jurisdictional claims in published maps and institutional affiliations.

Copyright: () 2022 by the authors Licensee MDPI, Basel, Switzerland. This article is an open access article distributed under the terms and conditions of the Creative Commons Attribution (CC BY) license (https:// creativecommons.org/licenses/by/ $4.0 /)$.

\begin{abstract}
This study examines the association between the effective corporate tax rate and the volatility of future effective corporate tax rates in Korean companies. We analyzed the effect of corporate governance on the association between tax avoidance and tax risk. Our sample is comprised of all the firms listed on the Korea Composite Stock Price Index market. We measure each firm's tax avoidance as GAAP ETR, Cash ETR, and BTD, and use the corporate governance rating of the Korea Corporate Governance Service to measure corporate governance. Our results show that the volatility of the effective corporate tax rate and the effective corporate tax rate would have a significant negative association. Our results show that tax risk decreases when the corporate tax avoidance level increases and the tax risk increases when the corporate tax avoidance level decreases. In addition, we find that the better the corporate governance structure, the higher the level of supervision and control of managers, thereby mitigating the impact of tax evasion on future corporate tax risk. The findings of this study regarding tax avoidance and corporate governance are important for investors because tax risk can significantly affect investor welfare.
\end{abstract}

Keywords: tax avoidance; sustainability management; tax risk

\section{Introduction}

This study examines the association between the effective corporate tax rate and the volatility of future effective corporate tax rates in Korean companies. We analyzed the effect of corporate governance on the association between tax avoidance and tax risk. Existing studies on the association between tax avoidance and tax risk mainly suggest that a high level of tax avoidance increases corporate tax risk. Hasan et al. [1] provided evidence that firms with a lower effective corporate tax rate due to a higher level of tax avoidance incur higher interest costs in financing debt. In contrast, Goh et al. [2] provided evidence that firms with higher levels of tax avoidance have lower costs of capital and argued that tax avoidance increases cash flow, thus investors demand a lower expected rate of return. Bauer and Klassen [3] found that there is no significant association between effective corporate tax rates (ETRs), a measure of tax avoidance, and actual future tax payments. They questioned whether the effective corporate tax rate at a low level properly reflects the tax avoidance that entails risk. Dyreng et al. [4] provided that some firms can maintain high levels of tax avoidance (low effective corporate tax rates) for long periods. Additionally, Guenther et al. [5] showed that the relatively low effective corporate tax rate is more sustainable than the relatively high effective corporate tax rate. In addition, they presented evidence that there is no significant association between the effective corporate tax rate, a measure of tax avoidance, and the volatility of the effective corporate tax rate, which is a measure of tax risk.

Existing studies suggest three reasons why tax avoidance increases corporate tax risk. The first reason is that corporate tax avoidance increases the possibility of incurring higher tax costs due to tax investigations and penalties from tax authorities in the future. The second reason is that companies lower their tax costs by avoiding them in a temporary way 
that cannot be used continuously in the future (Guenther, Matsunaga, and Williams [5]). Since such a temporary tax avoidance strategy cannot be maintained continuously, such tax avoidance entails more risk for companies. The third reason is that a firm's tax avoidance indicates that the firm is investing in high-risk investments.

In contrast, Dyreng et al. [4] argued that tax avoidance is not related to corporate risk because corporate tax avoidance refers to the ability of a corporation to invest in tax preferential investments, such as municipal funds, that are not subject to IRS restrictions or legal problems. They argued that continuous tax avoidance strategies are possible depending on the corporate environment and thus tax avoidance itself does not represent an investment with risk and does not increase uncertainty about future cash flows.

This study was conducted in two stages to verify the effect of corporate governance on the association between tax avoidance and tax risk. First, this study analyzed the association between the effective corporate tax rate and the volatility of future effective corporate tax rates. The first step aimed to analyze whether the tax avoidance strategy implemented by the company increases the uncertainty of the company's future tax rate. As suggested by previous studies, if a company implements a temporary tax avoidance strategy that cannot be maintained continuously in the future, the volatility of the effective corporate tax rate will increase in the future. Furthermore, if a tax avoidance strategy is being implemented through a tax preferential investment plan that can be continuously implemented according to the corporate environment, such as a municipal fund without IRS restrictions or legal problems, there will be no significant association between the effective corporate tax rate and the volatility of future effective corporate tax rates. For the first analysis, this study selected securities-listed companies from 2001 to 2017 as a sample and analyzed the association between the effective corporate tax rate (5-year GAAP ETR) and the standard deviation of the 5-year effective corporate tax rate. As a result of the analysis, this study found that tax risk decreased when a company's tax avoidance level increased and tax risk increased when a company's tax avoidance level decreased.

Second, this study analyzed the effect of corporate governance on the association between tax avoidance and tax risk. Foreign shareholders or independent outside directors will be able to alleviate uncertainty about the effective corporate tax rate in the future by maintaining a high level of supervision and control over management. In other words, companies with good corporate governance will allow management to keep the volatility of the effective corporate tax rate low. For this reason, there is an incentive for management to avoid tax through a more sustainable tax strategy. For the second stage of the analysis, this study selected the foreign ownership ratio, the independence of the board of directors, and the corporate governance rating of an external evaluation agency (Korea Corporate Governance Service, KCGS) as measures of corporate governance. As a result of the analysis, this paper found that the better the corporate governance of a company, the higher the level of supervision and control of managers, thereby alleviating the uncertainty of the effective corporate tax rate in the future.

Unlike most previous studies, this study contributes by providing new evidence on the association between tax avoidance and tax risk. This study suggests that tax risk decreases as the level of corporate tax avoidance increases, suggesting that various approaches should be taken in researching the effect of tax avoidance on tax risk in the future. In addition, by analyzing the effect of corporate governance on the association between tax avoidance and tax risk, we presented evidence that good corporate governance plays a role in controlling future corporate tax risk. Lastly, prior studies simply examine the association between tax avoidance persistence and tax risk. No prior study has analyzed the effect of corporate governance on management, determining tax strategy. This paper has the contribution of presenting empirical results that corporate governance plays a role in controlling future corporate tax risk. 


\section{Theoretical Background and Research Hypothesis}

\subsection{Tax Avoidance and Tax Risk}

Studies on the association between tax avoidance and tax risk mainly suggest that investment in tax avoidance increases corporate tax risk. Dyreng et al. [6] stated that tax avoidance is anything that reduces the firm's taxes relative to its pre-tax income. Additionally, Hanlon and Heitzman [7] stated that tax avoidance is thought of as a continuum of activities to reduce tax liability. It is difficult to maintain the tax avoidance strategy currently implemented by corporations in the future. In addition, it shows that the low tax rate due to tax avoidance will be reversed to a high tax rate in the future because it is a temporary investment that invests in tax cost reduction, which is one of several investment alternatives that involve risk.

Hasan et al. [1] suggested that there is a significant positive association between the level of corporate tax avoidance and the corporate bank loan spread. Shevlin et al. [8] provided evidence that there is a significant negative association between the effective corporate tax rate and the cost of debt. Existing studies related to tax avoidance mainly analyzed the association between tax avoidance and corporate characteristics or the association between tax avoidance and tax risk. Kang and Ko [9] stated that there is a significant negative relation between tax avoidance and corporate value by examining the role of corporate governance. In addition, Kang [10] tested the effect of tax avoidance and tax risk according to a company's tax strategy on the cost of embedded capital. They provided that, for groups with high levels of tax avoidance, the cost of capital increases when the level of tax avoidance increases, and for groups with low levels of tax avoidance, the cost of capital decreases when the level of tax avoidance increases. Kim et al. [11] tested the effect of tax avoidance on the association between company reputation and the implied cost of capital in Korean companies from 2003 to 2016. Kim et al. [11] reported that a significant negative association between company reputation and implied cost of capital is not found in a group that was aggressive in tax avoidance

As described above, existing studies mainly suggest that investment in tax avoidance increases the tax risk of companies. Existing studies provide three main reasons why tax avoidance increases corporate tax risk. First, the reason is that the low tax rate due to corporate tax evasion increases the possibility of a tax investigation from the tax authorities and the possibility of paying higher tax expenses due to tax investigations and penalties from the tax authorities in the future increases. In other words, the reduction of tax expenses due to tax avoidance entails additional corporate risk. Existing studies suggest the second reason is that corporations lower tax costs by avoiding taxes in a temporary way that can no longer be used in the future (Guenther, Matsunaga, and Williams [5]). Since the tax rate lowered by this tax strategy cannot be maintained continuously in the future, such tax avoidance entails more risk from the company's point of view. Third, existing studies argue that tax avoidance increases tax risk because a firm's low tax rate indicates that the firm is investing in a high-risk investment alternative. Finally, tax avoidance can incur agency costs and reduce corporate transparency, which can also bring uncertainty to a company's future cash flows.

Furthermore, Guenther et al. [5] presented the volatility of effective corporate tax rates as a measure of corporate risk and verified the association between tax strategy and corporate risk. However, Guenther et al. [5] found no evidence that, contrary to expectations, there is a significant association between corporate tax avoidance and corporate risk.

Dyreng et al. [4] argued that low effective corporate tax rates are not related to corporate risk because low effective corporate tax rates indicate the company's ability to invest in tax-preferred investments, such as municipal funds, that are free from IRS restrictions or legal problems. In other words, it is the concept that the current low effective corporate tax rate due to the corporate tax avoidance strategy will not be reversed to a higher tax rate in the future, nor will it increase the uncertainty of the actual future tax amount. In other words, companies can establish a sustainable tax avoidance strategy according to their environment or characteristics. They argue that, for this reason, a low effective corporate 
tax rate does not represent a risky investment, nor does it increase uncertainty about an entity's future cash flows. This study analyzed whether there is an association between the effective corporate tax rate, a measure of tax avoidance, and the volatility of the effective corporate tax rate, which is a measure of tax risk, for Korean companies as well.

\subsection{Tax Avoidance, Tax Risk, and Corporate Governance}

Shackelford and Shevlin [12] presented evidence that factors related to corporate governance are important determinants of tax avoidance. In addition, Wilson [13] presented evidence that tax benefit trading firms with good corporate governance generate higher excess returns than tax benefit trading firms with weak corporate governance. Hong et al. [14] analyzed the effect of the internal information environment on tax avoidance and tax risk, and presented evidence that the higher the quality of the internal information environment, the higher the level of tax avoidance and the lower the tax risk. Kang and Ko [9] presented evidence that there is a significant negative association between tax avoidance and corporate value by examining the role of corporate governance. In addition, Armstrong et al. [15] provided evidence that financial experts and independent outside directors mitigate the level of extreme tax avoidance in firms.

Goh et al. [2] provided evidence that there is a significant negative association between the level of tax avoidance and the cost of capital, and this phenomenon is prominent when corporate governance is better. The notion is that tax avoidance increases cash flow and therefore investors demand a lower expected rate of return.

Montenegro [16] tested the association between CSR, national governance, and tax evasion. Montenegro [16] provided evidence that the higher the national governance, the lower the level of tax avoidance. Additionally, Lee et al. [17] tested the association between the designation as the most admired firms and tax avoidance. Lee et al. [17] found that the firms designated as the most admired firms are reluctant to avoid taxes.

Based on the evidence from these existing studies, it can be inferred that firms with superior corporate governance will mitigate the increase in corporate risk due to tax avoidance than those with relatively weak corporate governance. Foreign shareholders or independent outside directors will be able to alleviate the uncertainty of future effective corporate tax rates caused by effective corporate tax rates by maintaining a high level of supervision and control over management. Based on these inferences, this study intends to examine the effect of corporate governance on the association between tax avoidance and corporate risk.

\section{Research Design}

\subsection{Research Hypothesis}

Tax avoidance is one of several investment options that involve risk (Armstrong et al. [15]). In other words, companies expect higher after-tax returns by embracing the increased risk of tax avoidance. Armstrong et al. [15] analyzed the association between corporate governance, management's pursuit of private interests, and tax avoidance. Armstrong et al. [15] provided evidence that managers tend to take higher tax avoidance than necessary when the level of the managerial pursuit of private interests is high. In addition, Park [18] analyzed the relationship between tax avoidance and managers pursuit of private profit, and suggested that tax avoidance increases overinvestment and reduces future profitability as well as wealth distribution. The study interprets the results as tax avoidance increases managers' pursuit of private interests. Based on the evidence of previous studies, the corporate tax avoidance strategy is impossible to sustain continuously in the future and is a temporary investment to reduce tax costs, which is one of the many risky investment alternatives. It can be inferred that in the future, this will be reversed with higher tax rates.

In addition, in the case of a company pursuing a low effective tax rate as a tax avoidance strategy to lower tax costs, it can be inferred that the company must take a higher risk and thus the uncertainty of the company's future effective tax rate will increase. It 
is difficult for corporations to continuously keep their tax burden at a low level and if a corporation lowers the effective tax rate for short-term tax avoidance, the volatility of the effective tax rate in the future will increase. This increase in the volatility of the effective corporate tax rate in the future may be due to the increase in the possibility of detection by the tax authorities, resulting in higher tax costs by paying additional tax and tax investigations from the tax authorities in the future. This may be due to the relatively high effective corporate tax rate being unavailable in the future. Based on this reasoning, Hypothesis 1 is established as follows to test the relation between the effective corporate tax rate and the volatility of the effective corporate tax rate.

Hypothesis 1 (H1). There is a significant negative association between the effective corporate tax rate and the future effective corporate tax rate volatility.

Hong et al. [14] analyzed the effect of the internal information environment on tax avoidance and tax risk, and presented evidence that the higher the quality of the internal information environment, the higher the level of tax avoidance and the lower the tax risk. Kang and Ko [9] presented evidence that there is a significant negative association between tax avoidance and corporate value by examining the role of corporate governance.

In addition, Armstrong et al. [15] provided evidence that financial experts and independent outside directors mitigate the level of extreme tax avoidance in firms. Goh et al. [2] provided evidence that there is a significant negative association between the level of tax avoidance and the cost of capital, and this phenomenon is prominent when corporate governance is better. This is interpreted as an increase in cash flow by tax avoidance and, accordingly, investors demand a lower expected rate of return.

Based on these existing studies, it can be inferred that there will be a change in the phenomenon established in Hypothesis 1 in the case of a company with relatively good corporate governance. In the case of a company with financial experts or independent outside directors, it will play a role in reducing the company's risk. In other words, a company with good corporate governance will encourage management to keep the volatility of the corporate effective corporate tax rate low. For this reason, there is an incentive for management to avoid tax through a more sustainable tax strategy. Based on this, Hypothesis 2 is established as follows.

Hypothesis 2 (H2). If corporate governance is better, the negative association between the effective corporate tax rate and the volatility of the effective corporate tax rate will be weakened.

\subsection{Research Model}

The purpose of this study was to verify the volatility of the effective corporate tax rate and to examine the effect of corporate governance on the sustainability and volatility of the effective corporate tax rate. Hypothesis 1 predicts that there is a significant negative association between the effective corporate tax rate and the future effective corporate tax rate volatility. To verify Hypothesis 1, regression analysis was performed by applying the model proposed by Guenther et al. [5] and Kang [10].

$$
\begin{aligned}
\text { ETRVol }_{t+1}=a_{0} & +a_{1} \text { YYearGETR }_{t}+a_{2} \text { Size }_{t}+a_{3} \text { PTBI }_{t}+a_{4} L V R_{t} \\
& +a_{5} \text { PTIVol }_{t}+a_{6} \text { AbnAcct }_{t}+a_{7} \text { RD }_{t}+a_{8} \text { FOR }_{t}+a_{9} \text { CFO }_{t} \\
& +a_{5} \text { CFOVol }_{t}+\Sigma Y E A R+\Sigma I D+\varepsilon_{t}
\end{aligned}
$$

$E T R V o l=$ standard deviation of GAAP ETR over 5 years.

5 YearGETR = a measure of GAAP ETR, which is the sum of corporate tax expense/pretax profit for 5 years.

Size $=\log$ value of total assets.

$P T B I=$ pre-tax profit $/$ basic total assets.

$L V R=$ total liabilities/basic total assets.

PTIVol $=$ 5-year pre-tax profit/standard deviation of underlying total assets . 
AbnAcc $=$ discretionary accrual as measured by the modified Jones model .

$R D=R \& D$ expenses $/$ basic total assets.

$F O R=$ common stock foreign investor share.

CFO = operating cash flow $/$ basic total assets.

CFOVol $=5$ years of operating cash flow $/$ standard deviation of underlying total assets.

$\sum Y E A R$ = year dummy variable.

$\sum I D=$ industry dummy variable.

ETRVol was set as the dependent variable. ETRVol was measured using the standard deviation of the effective corporate tax rate for 5 years from period $t-4$ to period $t$. As a variable of interest, 5 YearGETR, a measure of tax avoidance (effective corporate tax rate) in period $t$, was selected. 5YearGETR was calculated by dividing the company's 5-year corporate tax expense by the company's 5-year pre-tax profit. As the effective corporate tax rate decreases as the level of tax avoidance increases, it is expected that the coefficient of 5 YearGETR in Equation (1) will have a negative value.

To control the factors affecting the volatility of the effective corporate tax rate reported in previous studies, the company size and financial leverage (LVR) variables were included. In addition, PTBI and discretionary accrual $(A b n A c c)$ were included as control variables to control factors related to financial reporting. In addition, to control operating performance, the operating cash flow (CFO) and volatility of the operating cash flow (CFOVol) were included as control variables. In addition, the volatility of pre-tax profit (PTIVol), R\&D expenditure $(R D)$, and the foreign investor equity ratio $(F O R)$ were included as control variables.

Hypothesis 2 predicts that the negative association between the effective corporate tax rate and the volatility of the effective corporate tax rate will be weakened if corporate governance is better. To verify Hypothesis 2, regression analysis was performed, including the dummy variable GOV in Equation (1) presented by Guenther et al. [5] and Kang [10].

$$
\begin{aligned}
\text { ETRVol }_{t+1}=a_{0} & +a_{1,2,3} \text { GOV }_{t}+a_{4} \text { YYearGETR }_{t}+a_{5,6,7} \text { GOV } \times 5 \text { YearGETR } \\
& +a_{8} \text { Size }_{t}+a_{9} \text { PTBI }_{t}+a_{10} \text { LVR }_{t}+a_{11} \text { PTIVol }_{t} \\
& +a_{12} \text { AbnAcc }_{t}+a_{13} \text { RD }_{t}+a_{14} \text { FOR }_{t}+a_{15} \text { CFO }_{t} \\
& +a_{16} \text { CFOVol }_{t}+\Sigma Y \text { YAR }+\Sigma I D+\varepsilon_{t}
\end{aligned}
$$

$E T R V o l=$ standard deviation of GAAP ETR over 5 years.

$G O V=$ value measured by the following variables:

fordum: dummy variable with a value of 1 if the foreign ownership ratio is greater than the median value of the entire sample and 0 otherwise;

outratedum: an independence of the board of directors (a dummy variable with 1 if the ratio of outside directors among all registered directors is greater than the median value of the total sample and 0 otherwise); and

$\mathrm{ksg}$ : if the corporate governance rating of an external evaluation agency (Korea Corporate Governance Service) falls between the S-grade and A-grade (,$A_{+}$, and $A$ ), it has 1 , and if in the $\mathrm{B}+-\mathrm{D}$ grade $(\mathrm{B}+, \mathrm{B}, \mathrm{C}$, and $\mathrm{D})$, it has a dummy variable with 0 if applicable.

5 YearGETR = a measure of GAAP ETR, which is the sum of corporate tax expense/pretax profit for 5 years.

Size $=\log$ value of total assets.

$P T B I=$ pre-tax profit/basic total assets.

$L V R=$ total liabilities $/$ basic total assets.

$P T I V o l=5$-year pre-tax profit/standard deviation of underlying total assets.

$A b n A c c=$ discretionary accrual as measured by the modified Jones model.

$R D=R \& D$ expenses / basic total assets.

$F O R=$ common stock foreign investor share.

$C F O=$ operating cash flow $/$ basic total assets.

$C F O V o l=5$ years of operating cash flow /standard deviation of underlying total assets.

$\sum Y E A R$ = year dummy variable.

$\sum I D=$ industry dummy variable. 
Several prior studies tested the association between ownership structure and tax avoidance (Badertscher, Katz, and Rego [19]; McGuire, Wang, and Wilson [20]). Prior literature provided evidence that there is a significant positive association between institutional ownership and tax avoidance (Huseynov, Sardarli, and Zhang [21]; Khan, Srinivasan, and Tan [22]; Chen, Huang, Li, and Shevlin [23]). Armstrong et al. [15] used board independence and board expertise as a proxy for corporate governance. The natural logarithm of the number of financial experts on the board of directors was used as a measure of financial knowledge, which is the degree of a company's ability to measure the costs and benefits of tax avoidance. In addition, we used the proportion of outside directors in the board of directors as a measure of the ability and factors to monitor tax avoidance decisions. Kang and Ko [9] conducted a factor analysis by dividing corporate governance into internal and external governance structures to measure corporate governance and selected as well as analyzed the independence of the board of directors, institutional investor ownership ratio, and foreign ownership ratio. Park and Yeon [24] used the corporate governance rating of an external evaluation agency (Korea Corporate Governance Service) to measure corporate governance. In reference to this, this study also selected the foreign ownership ratio, the independence of the board of directors, and the corporate governance rating of an external evaluation agency (Korea Corporate Governance Service) as a proxy for corporate governance $(G O V)$ to measure the interaction variability between corporate governance $(G O V)$ and the effective corporate tax rate (TAXAVOID), which are interesting variables. Foreign ownership (for) was measured as the ratio of foreign stock holdings among all stocks and the independence of the board of directors (outrate) was measured by the ratio of outside directors among all registered directors. The corporate governance ratings of external rating agencies were measured by the Korea Corporate Governance Service. Hypothesis 2, which examines the effect of corporate governance on the association between tax avoidance and the volatility of the effective corporate tax rate, was tested through the coefficients of the interaction variable $(G O V \times 5$ YearGETR). If the values of the coefficients show significant positive values, it can be interpreted that the better the corporate governance structure, the weaker the negative relationship between tax avoidance and the volatility of the effective corporate tax rate, thus supporting Hypothesis 2. Therefore, this study expected the coefficients to show significant positive $(+)$ values.

\subsection{Measurement of Variables}

\subsubsection{Measurement of Tax Avoidance}

In existing studies, tax avoidance was measured using GAAP ETR, Cash ETR, and BTD. In this study, the degree of tax avoidance was measured using 5-Year GAAP ETR obtained by dividing the sum of the five-year corporate tax expense by the five-year pre-tax profit.

5 Year GAAP ETR = sum of corporate tax expenses for 5 years/sum of pre-tax income for 5 years.

5 Year GAAP ETR is a measure of the effective corporate tax rate of a company. A higher value can be interpreted as a lower level of tax avoidance and a lower value can be interpreted as a higher level of tax avoidance.

\subsubsection{Measurement of Effective Income Tax Rate Volatility}

As a measure of tax risk, which was the dependent variable in this study, Guenther et al. [5] and Kang [10] set the ETR volatility according to the method used. The 5-year GAAP ETR (effective corporate tax rate), used as a measure of the independent variable of tax avoidance, was measured as the standard deviation for 5 years from period $t-4$ to period $t$.

\subsubsection{Measurement of Corporate Governance}

Armstrong et al. [15] used board independence and board expertise as measures of corporate governance. The natural logarithm of the number of financial experts on the board of directors was used as a measure of financial knowledge, which is the degree of 
a company's ability to measure the costs and benefits of tax avoidance. In addition, the ratio of outside directors among the board of directors was used as a measure of the ability and factors to monitor tax avoidance decisions. Kang and Ko [9] conducted a factor analysis by dividing corporate governance into internal and external governance to measure corporate governance. Based on this, the independence of the board of directors, institutional investor ownership ratio, and foreign ownership ratio were selected and analyzed. Park and Yeon [24] used the corporate governance rating of an external evaluation agency (Korea Corporate Governance Service) to measure corporate governance. Accordingly, in this study, as a proxy for corporate governance (GOV), foreign ownership (for), the independence of the board of directors (outrate), and the corporate governance rating (Ksg) of an external evaluation agency (Korea Corporate Governance Service) were set to measure the interaction variable between corporate governance $(G O V)$ and the effective corporate tax rate (5Year GAAP ETR), which are variables of interest.

\subsubsection{Measurement of Foreign Ownership}

In this study, the foreign ownership ratio was measured as the ratio of stocks held by foreigners to the total number of stocks. Previous studies have provided evidence that the higher the foreign ownership ratio of a company, the less information asymmetry between the company and external stakeholders, and consequently the improvement of the company's information environment (Ahn et al. [25]). In other words, it can be said that foreign investors are playing an important role in corporate performance and corporate value as an external monitoring device. Accordingly, it can be interpreted that the larger the value of the foreign ownership ratio (fordum), the better the corporate governance structure. In this study, a dummy variable with a value of 1 was given if the foreign ownership ratio is greater than the median value of the entire sample and 0 otherwise, measured by high and low foreign equity ratios.

\subsubsection{Measurement of Board Independence}

In this study, the measure of the independence of the board of directors (outratedum) was measured as the ratio of outside directors to the total number of board members, which is the sum of the company's registered and outside directors. Previous studies have provided evidence that the higher the independence of the board, the higher the corporate performance (Byrd and Hickman 1992). Therefore, it can be interpreted that the larger the value of the measure of the independence of the board of directors (ourratedum), the better the corporate governance structure. In this study, the independence of the board of directors was measured as a dummy variable with a value of 1 if the ratio of outside directors among all registered directors was greater than the median value of the total sample and 0 otherwise.

\subsubsection{Corporate Governance Rating of the External Evaluation Agency (Korea Corporate} Governance Service)

In this study, corporate governance was measured using the corporate governance rating provided by the Korea Corporate Governance Service, which is an external evaluation agency, as a measure of corporate governance. Korea Corporate Governance has been providing corporate governance ratings for each company by evaluating corporate governance every year since 2003. The corporate governance grade provided by the Korea Corporate Governance Service consists of grades S to D (a total of 7 grades: S, A+, A, B+, B, $C$, and D). In this study, a dummy variable with a value of 1 when corporate governance grades fell between $\mathrm{S}$ grades and $\mathrm{A}$ grades $(\mathrm{S}, \mathrm{A}+$, and $\mathrm{A})$, and 0 when they fell between $\mathrm{B}+$ grades and $\mathrm{D}$ grades $(\mathrm{B}+, \mathrm{B}, \mathrm{C}$, and $\mathrm{D})$ was set.

\subsection{Selection of Samples}

In this study, samples were selected and analyzed from companies listed on the Korea Exchange from 2001 to 2017. To remove the influence by industry, the financial industry 
was excluded from the sample, and companies whose settlement month was not December were excluded. Negative (-) sales and total assets were excluded from the sample and negative $(-)$ pre-tax profits was excluded from the sample because it was judged that the incentives for corporate tax avoidance would be different. In addition, companies that could not measure the variables used in the study due to insufficient financial data were excluded from the sample. For the measurement of 5-Year GAAP ETR, if the corporate tax expense was less than zero, the corporate tax expense was adjusted to zero. Data from period $t-4$ was needed to measure the dependent variable ETR volatility and the independent variable of Hypothesis 1, which is the effective corporate tax rate (5-Year GAAP ETR). It was used for the empirical analysis and since the relation between the variables in the $t$ period and the dependent variable in the $t+1$ period was regression-analyzed, it was finally used for the empirical analysis up to 2016 data. In the case of Hypothesis 2, data on outside directors to measure the foreign ownership ratio and independence of the board of directors were available from 2005 to 2016, but data on corporate governance ratings of external evaluation agencies (Korea Corporate Governance Service) has been available for collection since 2011.

Therefore, the regression analysis using the foreign ownership ratio and the independence of the board of directors was conducted from 2005 to 2016, and the regression analysis using the corporate governance rating of an external evaluation agency (Korea Corporate Governance Service) was conducted from 2011 to 2016. In this study, the regression analysis was performed with data from 2005 to 2016 to verify Hypothesis 1 . In the case of Hypothesis 2 verification, the regression analysis using the corporate governance rating of an external evaluation agency (Korea Corporate Governance Service) was conducted with data from 2011 to 2016 . In this study, the regression analysis was performed with data from 2005 to 2016 to verify Hypothesis 1. In the case of Hypothesis 2 verification, the regression analysis using the corporate governance rating of an external evaluation agency (Korea Corporate Governance Service) was conducted with data from 2011 to 2016. Even when using data from 2016 to 2016, the variable of interest showed a significantly positive (+) relation with the dependent variable.

Even when using data from 2016 to 2016, the variable of interest showed a significantly positive $(+)$ relation with the dependent variable.

To minimize the influence of the extreme values, the values exceeding the upper and lower $1 \%$ of all variables were winsorized to the upper and lower $1 \%$. The foreign ownership ratio used in this study was extracted from TS2000 and other financial data were extracted from FnGuide's DataGuide. The corporate governance rating of an external rating agency (Korea Corporate Governance Service) was extracted from the website of the Korea Corporate Governance Service. Finally, a total of 4,734 firm-year observations were used for the analysis.

\section{Empirical Analysis}

\subsection{Descriptive Statistics and Correlation Analysis}

Table 1 shows the descriptive statistics of the main variables used in this study. For each variable, 4,734 company/year data were selected. The average value of the effective corporate tax rate (5Year GAAP ETR), used as a measure of tax avoidance in this study, was 0.248 and the median was 0.251 . It can be interpreted that companies listed on securities pay about $25 \%$ of their pre-tax profit as corporate tax. The volatility (etrvol) of the effective corporate tax rate, used as a measure of the tax risk of the dependent variable in this study, showed an average value of 0.027 and a median value of 0.018 . In the case of the foreign equity ratio, used as a measure of corporate governance to test Hypothesis 2, the average value of 0.116 and the median of 0.054 are shown, thus it can be interpreted that foreign investors are concentrated in a small number of companies.

Table 2 shows the correlation between major variables. In this study, the volatility (y_etrvol) of the effective corporate tax rate, used as a measure of the tax risk of the dependent variable, and the effective corporate tax rate (5Year GAAP ETR), used as a measure of the tax avoidance of the independent variable, were 0.134 , which was significant at the 
$5 \%$ level $(+)$, showing the relation. In other words, it was shown that tax risk increases when the level of corporate tax avoidance decreases and tax risk decreases when the level of tax avoidance increases. This is contrary to the results expected in the hypothesis. The purpose of this study was to test whether the univariate analysis correlation results are similar in the multivariate analysis regression analysis. In addition, the volatility of pre-tax profit, pre-tax profit volatility, the foreign ownership ratio, and operating cash flow showed a significant negative relation with the volatility of the effective corporate tax rate, and the leverage ratio was significant with the volatility of the effective corporate tax rate. It was found that there was a positive $(+)$ relation.

Table 1. Descriptive statistics.

\begin{tabular}{ccccccc}
\hline Variable & $\mathbf{N}$ & Mean & SD & P25 & P50 & P75 \\
\hline etrvol & 4734 & 0.027 & 0.026 & 0.009 & 0.018 & 0.036 \\
5yearGETR & 4734 & 0.248 & 0.083 & 0.211 & 0.251 & 0.289 \\
size & 4734 & 13.259 & 1.569 & 12.118 & 12.979 & 14.110 \\
ptbi & 4734 & 0.078 & 0.062 & 0.032 & 0.062 & 0.106 \\
lvr & 4734 & 0.506 & 0.248 & 0.314 & 0.487 & 0.657 \\
ptivol & 4734 & 0.037 & 0.030 & 0.017 & 0.029 & 0.047 \\
abnacc & 4734 & 0.007 & 0.070 & -0.030 & 0.004 & 0.041 \\
rd & 4734 & 0.007 & 0.014 & 0.000 & 0.001 & 0.006 \\
for & 4734 & 0.116 & 0.146 & 0.010 & 0.054 & 0.170 \\
cfo & 4734 & 0.074 & 0.080 & 0.028 & 0.066 & 0.115 \\
cfovol & 4734 & 0.060 & 0.044 & 0.032 & 0.048 & 0.075
\end{tabular}

Variables are defined as follows: etrvol = the standard deviation of five annual GAAP ETRs (the sum of tax expense over a five-year period scaled by the sum of pre-tax income over the same period); 5year GETR = the sum of tax expense over a five-year period scaled by the sum of pre-tax income over the same period; Size = natural of total assets; $p t b i=$ pre-tax book income scaled by lagged total assets; $l v r=$ year-end total debt scaled by lagged total assets; $p$ tivol = standard deviation of annual pre-tax income scaled by lagged total assets measured over a five-year period; $a b n a c c=$ square of year-end discretionary accruals estimated using the modified Jones model from Dechow, Sloan, and Sweeney (1996); $r d$ = research and development expense scaled by lagged total assets; for $=$ the proportion of common shares held by foreigners; $c f o=$ operating cash flow (OCF) scaled by lagged total assets; and $c$ fovol = standard deviation of operating cash flow (OCF) scaled by lagged total assets measured over a five-year period.

Table 2. Pairwise correlations.

\begin{tabular}{|c|c|c|c|c|c|c|c|c|c|c|c|}
\hline Variables & (1) & (2) & (3) & (4) & (5) & (6) & (7) & (8) & (9) & (10) & (11) \\
\hline (1) y_etrvol & 1.000 & & & & & & & & & & \\
\hline $\begin{array}{c}\text { (2) } 5 \text { Year } \\
\text { GAAP ETR }\end{array}$ & 0.134 * & 1.000 & & & & & & & & & \\
\hline (3) size & 0.006 & $0.112 *$ & 1.000 & & & & & & & & \\
\hline (4) $p t b i$ & -0.184 * & $-0.037^{*}$ & -0.065 * & 1.000 & & & & & & & \\
\hline (5) lor & $0.202 *$ & $0.094 *$ & 0.290 * & -0.132 * & 1.000 & & & & & & \\
\hline (6) ptivol & -0.103 * & -0.115 * & -0.064 * & $0.419 *$ & -0.066 * & 1.000 & & & & & \\
\hline (7) abnacc & 0.004 & -0.022 & -0.079 * & $0.111 *$ & 0.064 * & 0.064 * & 1.000 & & & & \\
\hline (8) $r d$ & -0.018 & -0.009 & 0.030 * & 0.125 * & $-0.039 *$ & 0.093 * & $-0.052 *$ & 1.000 & & & \\
\hline (9) for & $-0.161 *$ & 0.084 * & 0.454 * & $0.243 *$ & $-0.069 *$ & 0.052 * & $-0.079 *$ & 0.090 * & 1.000 & & \\
\hline (10) cfo & $-0.102 *$ & -0.070 * & $0.047 *$ & $0.483 *$ & -0.081 * & $0.189 *$ & -0.769 * & 0.111 * & $0.205 *$ & 1.000 & \\
\hline (11) cfovol & $-0.032 *$ & $-0.056^{*}$ & $-0.070 *$ & $0.197^{*}$ & 0.165 * & 0.453 * & 0.011 & $0.066^{*}$ & -0.050 * & 0.102 * & 1.000 \\
\hline
\end{tabular}

* shows significance at the 0.05 level.

\subsection{Tax Avoidance and Volatility of Effective Corporate Tax Rates}

Table 3 shows the results of a regression analysis on the relation between the effective corporate tax rate (5Year GAAP ETR), used as a measure of tax avoidance, which is an independent variable, and the volatility of the effective corporate tax rate (ETR), used as a measure of tax risk, which is a dependent variable. Hypothesis 1 predicted that the volatility of the effective corporate tax rate and the effective corporate tax rate would have a significant negative association because it was difficult for a corporation to select a sustainable tax avoidance strategy. However, contrary to the prediction of the hypothesis, it was found that there is a positive $(+)$ relation between the effective corporate tax rate 
and the volatility of the effective corporate tax rate. The coefficient of 5-Year GETR was 0.051 , which showed a significantly positive $(+)$ value at the $1 \%$ level. As the effective corporate tax rate increases, the volatility of the effective corporate tax rate increases, and as the effective corporate tax rate decreases, the volatility of the effective corporate tax rate decreases. In other words, as the corporate tax avoidance level increases, tax risk decreases, and as the corporate tax avoidance level decreases, the tax risk increases. Hypothesis 1 was not supported. This is described in Guenther et al. [5], which had the same results. Guenther et al. [5] predicted that a low effective corporate tax rate would have a positive (+) relation with the future effective corporate tax rate volatility but the results of the analysis showed that the low effective corporate tax rate and future effective corporate tax rate volatility were partially negatively $(-)$ found to be related. These results indicate that corporate tax avoidance is not related to corporate tax risk.

Table 3. The relation between tax avoidance measure and future rate volatility.

\begin{tabular}{|c|c|c|c|c|}
\hline & \multirow[b]{2}{*}{ Expectation } & \multicolumn{3}{|c|}{ GAAP ETR Volatilty } \\
\hline & & Coef. & St.Err & $t$-Stat. \\
\hline 5YearGETR & - & $\begin{array}{c}0.051 * * * \\
(0.005)\end{array}$ & 0.050 & 10.79 \\
\hline size & - & $\begin{array}{c}-0.001^{* * *} \\
(0.000)\end{array}$ & 0.000 & -4.27 \\
\hline$p t b i$ & & $\begin{array}{c}-0.058^{* * *} \\
(0.014)\end{array}$ & 0.014 & -4.07 \\
\hline lor & + & $\begin{array}{c}0.021^{* * *} \\
(0.002)\end{array}$ & 0.002 & 12.26 \\
\hline ptivol & & $\begin{array}{l}-0.022 \\
(0.015)\end{array}$ & 0.015 & -1.51 \\
\hline abnacc & - & $\begin{array}{l}0.031 \text { * } \\
(0.017)\end{array}$ & 0.017 & 1.83 \\
\hline$r d$ & & $\begin{array}{l}-0.000 \\
(0.030)\end{array}$ & 0.030 & -0.01 \\
\hline for & - & $\begin{array}{c}-0.016^{* * *} \\
(0.003)\end{array}$ & 0.003 & -5.12 \\
\hline$c f o$ & - & $\begin{array}{l}0.036^{* *} \\
(0.017)\end{array}$ & 0.017 & 2.12 \\
\hline cfovol & + & $\begin{array}{l}-0.007 \\
(0.010)\end{array}$ & 0.010 & -0.71 \\
\hline _cons & & $\begin{array}{c}0.025^{* * *} \\
(0.006)\end{array}$ & 0.006 & 4.44 \\
\hline Obs. & & 4734 & & \\
\hline$R$-squared & & 0.185 & & \\
\hline Year dummy & & yes & & \\
\hline Industry Dummy & & yes & & \\
\hline
\end{tabular}

The leverage ratio (lvr) and operating cash flow (cfo), used as control variables, were found to have a significantly positive $(+)$ relation with the volatility of the effective corporate tax rate and a significant negative relation with the volatility of the effective corporate tax rate.

\subsection{Tax Avoidance, Volatility of Effective Corporate Tax Rates, and Corporate Governance}

Table 4 shows the results of the analysis on the effect of corporate governance on the association between tax avoidance and the volatility of effective corporate tax rates. In Hypothesis 2, this study predicted that the better the corporate governance structure, the more relaxed the negative relation between the effective corporate tax rate and the volatility of the effective corporate tax rate. However, in the verification of Hypothesis 1, contrary to expectations, it was found that there is a significantly positive $(+)$ relation between the volatility of the effective corporate tax rate and the effective corporate tax rate. $\times 5$ Year (GETR) does not show a significant value or shows a significant negative value, thus it can 
be interpreted that corporate governance affects the relation between tax avoidance and the volatility of the effective corporate tax rate.

Table 4. The relation between governance * tax avoidance and future rate volatility.

\begin{tabular}{|c|c|c|c|}
\hline \multirow[t]{2}{*}{ Panel A: } & \multicolumn{3}{|c|}{ Gov1 = Fordum $*$ 5-Year GETR } \\
\hline & Coef. & St.Err & $t$-Stat. \\
\hline 5-Year ETR & $\begin{array}{c}0.056^{* * *} \\
(0.006)\end{array}$ & 0.006 & 9.39 \\
\hline fordum & $\begin{array}{c}0.000 \\
(0.002)\end{array}$ & 0.002 & 0.11 \\
\hline fordum*5-Year ETR & $\begin{array}{l}-0.014 \\
(0.009)\end{array}$ & 0.009 & -1.54 \\
\hline size & $\begin{array}{c}-0.002^{* * *} \\
(0.000)\end{array}$ & 0.000 & -5.01 \\
\hline ptbi & $\begin{array}{c}-0.060^{* * *} \\
(0.014)\end{array}$ & 0.014 & -4.25 \\
\hline $\operatorname{lvr}$ & $\begin{array}{c}0.022^{* * *} \\
(0.002)\end{array}$ & 0.002 & 12.69 \\
\hline ptivol & $\begin{array}{l}-0.021 \\
(0.015)\end{array}$ & 0.015 & -1.41 \\
\hline abnacc & $\begin{array}{l}0.029 \text { * } \\
(0.017)\end{array}$ & 0.017 & 1.72 \\
\hline rd & $\begin{array}{l}-0.005 \\
(0.030)\end{array}$ & 0.030 & -0.15 \\
\hline cfo & $\begin{array}{c}0.033 * * \\
(0.017)\end{array}$ & 0.017 & 1.99 \\
\hline cfovol & $\begin{array}{l}-0.006 \\
(0.010)\end{array}$ & 0.010 & -0.59 \\
\hline _cons & $\begin{array}{c}0.027 * * * \\
(0.006)\end{array}$ & 0.006 & 4.74 \\
\hline Obs. & 4734 & & \\
\hline R-squared & 0.183 & & \\
\hline Year dummy & yes & & \\
\hline Industry dummy & yes & & \\
\hline \multirow[t]{2}{*}{ Panel B: } & \multicolumn{3}{|c|}{ gov2 = outratedum ${ }^{*} 5-Y e a r$ GETR } \\
\hline & Coef. & St.Err & $t$-Value \\
\hline 5-Year GETR & $\begin{array}{c}0.075^{* * *} \\
(0.008)\end{array}$ & 0.008 & 9.01 \\
\hline outratedum & $\begin{array}{c}0.002 \\
(0.003)\end{array}$ & 0.003 & 0.57 \\
\hline outratedum*5-Year GETR & $\begin{array}{l}-0.008 \\
(0.012)\end{array}$ & 0.012 & -0.63 \\
\hline size & $\begin{array}{c}-0.002^{* * *} \\
(0.000)\end{array}$ & 0.000 & -3.58 \\
\hline ptbi & $\begin{array}{c}-0.045^{* *} \\
(0.020)\end{array}$ & 0.020 & -2.29 \\
\hline $\operatorname{lvr}$ & $\begin{array}{c}0.029 * * * \\
(0.002)\end{array}$ & 0.002 & 11.83 \\
\hline ptivol & $\begin{array}{l}-0.033 \\
(0.020)\end{array}$ & 0.020 & -1.63 \\
\hline abnacc & $\begin{array}{c}0.025 \\
(0.022)\end{array}$ & 0.022 & 1.14 \\
\hline $\mathrm{rd}$ & $\begin{array}{c}0.043 \\
(0.041)\end{array}$ & 0.041 & 1.06 \\
\hline for & $\begin{array}{c}-0.015^{* * *} \\
(0.005)\end{array}$ & 0.005 & -3.15 \\
\hline cfo & $\begin{array}{c}0.026 \\
(0.022)\end{array}$ & 0.022 & 1.17 \\
\hline
\end{tabular}


Table 4. Cont.

\begin{tabular}{|c|c|c|c|}
\hline \multirow[t]{2}{*}{ Panel B: } & \multicolumn{3}{|c|}{ gov2 $=$ outratedum $* 5-Y e a r$ GETR } \\
\hline & Coef. & St.Err & $t$-Value \\
\hline cfovol & $\begin{array}{l}-0.001 \\
(0.014)\end{array}$ & 0.014 & -0.04 \\
\hline _cons & $\begin{array}{c}0.031^{* * * *} \\
(0.008)\end{array}$ & 0.008 & 4.00 \\
\hline Obs. & 2906 & & \\
\hline R-squared & 0.202 & & \\
\hline Year dummy & yes & & \\
\hline Industry dummy & yes & & \\
\hline \multirow[t]{2}{*}{ Panel C: } & \multicolumn{3}{|c|}{ gov3 = Ksg*5-Year GETR } \\
\hline & Coef. & St.Err & $t$-Value \\
\hline 5-Year GETR & $\begin{array}{c}0.085^{* * *} \\
(0.007)\end{array}$ & 0.007 & 11.97 \\
\hline Ksg & $\begin{array}{c}0.010 \\
(0.009)\end{array}$ & 0.009 & 1.16 \\
\hline Ksg*5-Year GETR & $\begin{array}{l}-0.013 \\
(0.033)\end{array}$ & 0.033 & -0.40 \\
\hline size & $\begin{array}{c}-0.002 * * * \\
(0.000)\end{array}$ & 0.000 & -4.52 \\
\hline ptbi & $\begin{array}{c}-0.047^{* *} \\
(0.021)\end{array}$ & 0.021 & -2.21 \\
\hline $\operatorname{lvr}$ & $\begin{array}{c}0.033^{* * *} \\
(0.003)\end{array}$ & 0.003 & 12.60 \\
\hline ptivol & $\begin{array}{l}-0.015 \\
(0.022)\end{array}$ & 0.022 & -0.71 \\
\hline abnacc & $\begin{array}{c}0.024 \\
(0.024)\end{array}$ & 0.024 & 0.98 \\
\hline rd & $\begin{array}{c}0.060 \\
(0.044)\end{array}$ & 0.044 & 1.36 \\
\hline for & $\begin{array}{c}-0.013^{* * *} \\
(0.005)\end{array}$ & 0.005 & -2.61 \\
\hline cfo & $\begin{array}{c}0.023 \\
(0.024)\end{array}$ & 0.024 & 0.92 \\
\hline cfovol & $\begin{array}{l}-0.005 \\
(0.015)\end{array}$ & 0.015 & -0.33 \\
\hline _cons & $\begin{array}{c}0.031 * * * \\
(0.008)\end{array}$ & 0.008 & 3.78 \\
\hline Obs. & 2561 & & \\
\hline R-squared & 0.231 & & \\
\hline Year dummy & yes & & \\
\hline industry dummy & yes & & \\
\hline \multirow[t]{2}{*}{ Panel D: } & \multicolumn{3}{|c|}{ (govdum1 govdum3)*5-Year GETR } \\
\hline & Coef. & St.Err & $t$-Value \\
\hline 5-Year GETR & $\begin{array}{c}0.089 * * * \\
(0.010)\end{array}$ & 0.010 & 8.99 \\
\hline fordum & $\begin{array}{l}-0.001 \\
(0.004)\end{array}$ & 0.004 & -0.19 \\
\hline outratedum & $\begin{array}{c}0.002 \\
(0.003)\end{array}$ & 0.003 & 0.65 \\
\hline $\mathrm{ksg}$ & $\begin{array}{c}0.008 \\
(0.009)\end{array}$ & 0.009 & 0.93 \\
\hline Fordum*5-Year GETR & $\begin{array}{l}-0.008 \\
(0.014)\end{array}$ & 0.014 & -0.56 \\
\hline Outratedum*5-Year GETR & $\begin{array}{l}-0.007 \\
(0.013)\end{array}$ & 0.013 & -0.53 \\
\hline Ksg*5-Year GETR & $\begin{array}{l}-0.009 \\
(0.034)\end{array}$ & 0.034 & -0.27 \\
\hline
\end{tabular}


Table 4. Cont.

\begin{tabular}{|c|c|c|c|}
\hline \multirow[t]{2}{*}{ Panel D: } & \multicolumn{3}{|c|}{ (govdum1 govdum3)*5-Year GETR } \\
\hline & Coef. & St.Err & $t$-Value \\
\hline size & $\begin{array}{c}-0.002^{* * *} \\
(0.000)\end{array}$ & 0.000 & -4.61 \\
\hline ptbi & $\begin{array}{c}-0.049^{* *} \\
(0.022)\end{array}$ & 0.022 & -2.29 \\
\hline $\operatorname{lvr}$ & $\begin{array}{c}0.034^{* * * *} \\
(0.003)\end{array}$ & 0.003 & 12.83 \\
\hline ptivol & $\begin{array}{l}-0.015 \\
(0.022)\end{array}$ & 0.022 & -0.69 \\
\hline abnacc & $\begin{array}{c}0.023 \\
(0.024)\end{array}$ & 0.024 & 0.93 \\
\hline rd & $\begin{array}{c}0.058 \\
(0.044)\end{array}$ & 0.044 & 1.31 \\
\hline cfo & $\begin{array}{c}0.020 \\
(0.025)\end{array}$ & 0.025 & 0.81 \\
\hline cfovol & $\begin{array}{l}-0.002 \\
(0.015)\end{array}$ & 0.015 & -0.12 \\
\hline _cons & $\begin{array}{c}0.031 * * * \\
(0.009)\end{array}$ & 0.009 & 3.66 \\
\hline Obs. & 2507 & & \\
\hline R-squared & 0.232 & & \\
\hline Year dummy & yes & & \\
\hline industry dummy & yes & & \\
\hline
\end{tabular}

Panel A of Table 4 presents the results when foreign ownership (fordum) was used as a measure of corporate governance. The coefficient value of fordum ${ }^{*}$ YearGETR was -0.014 , which was negative $(-)$, but showed an insignificant coefficient value. These results can be interpreted as alleviating the uncertainty of the effective corporate tax rate in the future, caused by the effective corporate tax rate, as the higher the foreign ownership ratio, the higher the level of supervision and control of managers. In addition, when the foreign ownership ratio was not high, the coefficient of '5-Year ETR', which is a variable representing the volatility of the effective corporate tax rate in the future, brought about by the effective corporate tax rate, was 0.056 , which shows a significant positive (+) value. Most of the uncertainty in the effective corporate tax rate in the future can be interpreted as the result of companies with relatively weak corporate governance because the foreign ownership ratio is not high.

Panel B of Table 4 presents the results of the analysis using the independence (outratedum) of the board of directors as a measure of corporate governance. The coefficient value of outratedum $* 5$ YearGETR was also negative $(-)$ at -0.008 but showed an insignificant coefficient value. These results show that the higher the number of outside directors within the board of directors, the more objective the management is monitored and controlled, thereby alleviating the uncertainty of the effective corporate tax rate in the future caused by the effective corporate tax rate. Additionally, when the independence of the board of directors was not high, the coefficient of '5Year ETR', which is a variable representing the volatility of future effective corporate tax rates brought about by the effective corporate tax rate, was 0.075 , showing a significant positive $(+)$ value. The uncertainty of the effective corporate tax rate in the future, brought about by the tax rate, can be interpreted as a result of a company with a relatively weak corporate governance structure due to the low independence of the board of directors.

Panel C of Table 4 shows the analysis results using the corporate governance rating $(\mathrm{ksg})$ of an external evaluation agency (Korea Corporate Governance Service) as a measure of corporate governance. The coefficient value of $\mathrm{ksg}^{* 5}$ YearGETR was also negative (-) at -0.013 but showed an insignificant coefficient value. These results can be interpreted as alleviating the uncertainty in the future effective corporate tax rate caused by the effective 
corporate tax rate because the better the corporate governance structure, the higher the level of supervision and control of managers. In addition, when the corporate governance rating (ksg) of an external rating agency (Korea Corporate Governance Service) was not high, the coefficient of '5Year ETR', which is a variable representing the volatility of future effective corporate tax rates brought about by effective corporate tax rates, showed a significantly positive $(+)$ value of 0.085 , and the uncertainty of the future effective corporate tax rate brought about by the effective corporate tax rate is mostly due to the relatively low corporate governance rating $(\mathrm{ksg})$ of an external rating agency (Korea Corporate Governance Service). It can be interpreted as a result of a company judged to be a company with a weak governance structure.

Panel D of Table 4 measures the net effect of corporate governance variables and removes the mutual influence of corporate governance variables. It shows the results of the regression analysis by including both the interaction terms between the corporate governance rating $((\mathrm{ksg})$ of the original) and the effective corporate tax rate (5YearGETR), which is a measure of tax avoidance. In this case as well, similarly to the previous result, the coefficients of the interaction variables all showed negative $(-)$ values but did not show significant values. This can be interpreted as alleviating the uncertainty of future effective corporate tax rates brought about by the corporate tax rate. Additionally, in this case, the coefficient of the variable '5Year GETR' was 0.089, showing a significant positive value, and the uncertainty of the future effective corporate tax rate brought about by the effective corporate tax rate is mostly for companies with relatively weak corporate governance. It can be interpreted as a result of the company judged.

\section{Conclusions}

Studies on the relation between existing tax avoidance and tax risk mainly suggest that a high level of tax avoidance increases the tax risk of a company. Previous studies have shown that corporate tax evasion increases the likelihood of corporate tax audits, increases the likelihood of paying higher tax costs due to tax audits and penalties from tax authorities, and is a temporary method that corporations cannot use continuously in the future. The reason is that it lowers tax costs by doing so. In other words, a firm's tax avoidance indicates that the firm is investing in a high-risk investment alternative.

In this study, Guenther et al. [5] analyzed the relation between the effective corporate tax rate and the volatility of future effective corporate tax rates. In addition, the effect of corporate governance on the relation between tax avoidance and tax risk was verified. For the analysis, the foreign ownership ratio, the independence of the board of directors, and the corporate governance rating of an external evaluation agency (Korea Corporate Governance Service) were selected as measures of corporate governance for the analysis.

As a result of the analysis, tax risk decreases when the corporate tax avoidance level increases (effective corporate tax rate decreases) and tax risk increases when the corporate tax avoidance level decreases (effective corporate tax rate increases). Guenther et al. [5] found the same results. In other words, we presented evidence that corporate tax avoidance strategies do not increase corporate tax risk. In addition, it was found that the better the corporate governance structure, the higher the level of supervision and control of managers, thereby mitigating the impact of tax evasion on future corporate tax risk.

Our paper has some contributions. Unlike most previous studies, this study contributes by providing new evidence on the association between tax avoidance and tax risk. This study suggests that tax risk decreases as the level of corporate tax avoidance increases, suggesting that various approaches should be taken in researching the effect of tax avoidance on tax risk in the future. In addition, by analyzing the effect of corporate governance on the association between tax avoidance and tax risk, we presented evidence that good corporate governance plays a role in controlling future corporate tax risk. Lastly, prior studies simply examined the association between tax avoidance persistence and tax risk. No prior study has analyzed the effect of corporate governance on management, thereby determining tax strategy. This paper has the contribution of presenting empirical results that corporate governance plays a role in controlling future corporate tax risk. 
However, this paper has a limitation. Our paper focused on Korean firms. Additionlly, this paper considered only the foreign ownership ratio, independence of the board of directors, and corporate governance rating for corporate governance. Future research may consider management compensation and audits for corporate governance.

Author Contributions: Conceptualization, J.C. and H.P.; formal analysis, J.C.; methodology, J.C.; investigation, H.P.; data curation, H.P.; writing —original draft preparation, J.C. and H.P.; writingreview and editing, J.C. and H.P. All authors have read and agreed to the published version of the manuscript. The authors declare no conflict of interest.

Funding: This research received no external funding.

Institutional Review Board Statement: Not applicable.

Informed Consent Statement: Not applicable.

Conflicts of Interest: The authors declare no conflict of interest.

\section{References}

1. Hasan, I.; Hoi, C.K.S.; Wu, Q.; Zhang, H. Beauty is in the eye of the beholder: The effect of corporate tax avoidance on the cost of bank loans. J. Financ. Econ. 2014, 113, 109-130. [CrossRef]

2. Goh, B.W.; Lee, J.; Lim, C.Y.; Shevlin, T. The Effect of Corporate Tax Avoidance on the Cost of Equity. Account. Rev. 2016, 91, 1647-1670. [CrossRef]

3. Bauer, A.; Kenneth, J.K. Tax Risk as the Likelihood of an Unfavorable Settlement with Tax Authorities. 2014. Available online: https:/ / papers.ssrn.com/sol3/papers.cfm?abstract_id=2403946 (accessed on 1 January 2022).

4. Dyreng, S.D.; Hanlon, M.; Maydew, E.L. Long-Run Corporate Tax Avoidance. Account. Rev. 2008, 83, 61-82. [CrossRef]

5. Guenther, D.A.; Matsunaga, S.R.; Williams, B.M. Is Tax Avoidance Related to Firm Risk? Account. Rev. 2016, 92, 115-136. [CrossRef]

6. Dyreng, S.D.; Hanlon, M.; Maydew, E.L. The Effects of Executives on Corporate Tax Avoidance. Account. Rev. 2010, 85, 1163-1189. [CrossRef]

7. Hanlon, M.; Heitzman, S. A review of tax research. J. Account. Econ. 2010, 50, 127-178. [CrossRef]

8. Shevlin, T.; Urcan, O.; Vasvari, F.P. Corporate Tax Avoidance and Public Debt Costs. J. Am. Tax. Assoc. 2020, 42, 117-143. [CrossRef]

9. Kang, J.; Ko, J. Tax Avoidance, Firm Value and Corporate Governance. Korean Account. Rev. 2014, 39, 147-183.

10. Kang, J. Tax Avoidance, Firm Value and Tax Risk. Korea Int. Account. Rev. 2018, 78, 245-270.

11. Kim, I.; Kim, J.; Kang, J. Company Reputation, Implied Cost of Capital and Tax Avoidance: Evidence from Korea. Sustainability 2020, 12, 9997. [CrossRef]

12. Shackelford, D.A.; Shevlin, T. Empirical tax research in accounting. J. Account. Econ. 2001, 31, 321-387. [CrossRef]

13. Wilson, R.J. An Examination of Corporate Tax Shelter Participants. Account. Rev. 2009, 84, 969-999. [CrossRef]

14. Hong, O.H.; Ko, J.K.; Park, H.J. The Effect of Internal Information Environment on Tax Avoidance and Tax Risk. Korean Account. J. 2018, 27, 79-112. [CrossRef]

15. Armstrong, C.S.; Blouin, J.L.; Jagolinzer, A.D.; Larcker, D.F. Corporate governance, incentives, and tax avoidance. J. Account. Econ. 2015, 60, 1-17. [CrossRef]

16. Montenegro, T.M. Tax Evasion, Corporate Social Responsibility and National Governance: A Country-Level Study. Sustainability 2021, 13, 11166. [CrossRef]

17. Lee, J.; Kim, S.; Kim, E. Designation as the Most Admired Firms to the Sustainable Management of Taxes: Evidence from South Korea. Sustainability 2021, 13, 7994. [CrossRef]

18. Park, S.W. Tax Avoidance and Managerial Rent Extraction. Korean Account. Rev. 2018, 43, 183-223. [CrossRef]

19. Badertscher, B.A.; Katz, S.P.; Rego, S. The separation of ownership and control and corporate tax avoidance. J. Account. Econ. 2013, 56, 228-250. [CrossRef]

20. McGuire, S.T.; Wang, D.; Wilson, R.J. Dual Class Ownership and Tax Avoidance. Account. Rev. 2014, 89, 1487-1516. [CrossRef]

21. Huseynov, F.; Sardarli, S.; Zhang, W. Does index addition affect corporate tax avoidance? J. Corp. Financ. 2017, 43, 241-259. [CrossRef]

22. Khan, M.; Srinivasan, S.; Tan, L. Institutional Ownership and Corporate Tax Avoidance: New Evidence. Account. Rev. 2016, 92, 101-122. [CrossRef]

23. Chen, S.; Huang, Y.; Li, N.; Shevlin, T. How does quasi-indexer ownership affect corporate tax planning? J. Account. Econ. 2019, 67, 278-296. [CrossRef]

24. Park, S.; Yeon, K. The Effect of Corporate Governance on the Level of a Firm's Cash Holdings. Asian Rev. Financ. Res. 2009, $22,1-36$.

25. Ahn, Y.; Shin, H.; Chang, J. The Relationship between the Foreign Investor and Information Asymmetry. Korean Account. Rev. 2005, 30, 109-131. 